\title{
Penentuan Tempat Pembuangan Akhir Sampah di Kabupaten Sumedang Menggunakan Pemodelan Spasial
}

\author{
HARY NUGROHO, MELAN NANO FIRMANSYAH
}

\author{
Jurusan Teknik Geodesi \\ FTSP - Institut Teknologi Nasional, Bandung \\ Email: hary@itenas.ac.id
}

\begin{abstract}
ABSTRAK
Jumlah penduduk Kabupaten Sumedang saat ini mencapai 1.125.125 jiwa dengan tingkat buangan sampah per hari pada tahun 2014 mencapai $3.270 \mathrm{~m}^{3}$. Adapun volume sampah yang tertangani per hari oleh pemerintah Kabupaten Sumedang melalui Badan Lingkungan Hidup baru mencapai $150 \mathrm{~m}^{3}$. Kondisi ini terjadi sebagai akibat akumulasi berbagai permasalahan penanganan sampah. Salah satu di antaranya adalah Tempat Pembuangan Akhir (TPA) Sampah. TPA yang saat ini digunakan, yaitu TPA di Kecamatan Cimalaka Desa Cibeureum Wetan, sudah tidak layak. Oleh karena itu perlu dilakukan pencarian lahan yang dapat dijadikan lokasi tempat pembuangan sampah akhir yang dapat menampung sampah dalam kurun waktu yang lama. Penentuan lokasi TPA baru harus mengikuti kriteria standar seperti yang tertulis dalam SNI No. 03-3241-1994 dan Peraturan Menteri Pekerjaan Umum Nomor 3/PRT/M/2013. Dalam penelitian ini, lokasi TPA terbaik ditentukan melalui analisis kesesuaian dengan menggunakan pemodelan spasial. Adapun parameter yang digunakan dalam pemodelan terdiri atas: jenis tanah, jenis batuan, tata guna lahan, kemiringan tanah, kepadatan lalu lintas, hidrogeologi, curah hujan, dan batas administrasi. Hasil pemodelan menunjukkan terdapat 45 titik sebaran lokasi yang berpotensi untuk dijadikan TPA Sampah dengan waktu pengoperasian lebih dari 5 tahun.
\end{abstract}

Kata kunci: TPA Sampah, Pemodelan Spasial, SNI

\begin{abstract}
The population of Sumedang Regency currently reaches 1,125,125 people with waste disposal in 2014 reached $3,270 \mathrm{~m}^{3}$. The volume of waste which can be handled daily by the district government through the Environment Agency has only reached $150 \mathrm{~m}^{3}$. This condition occurs as a result of the accumulation of various problems of waste management. One of them is the Final Disposal Site (TPA) of Garbage. The TPA currently used, TPA in Cimalaka Village Cibeureum Wetan Village, is no longer feasible. Therefore it is necessary to search for the land that can be used as the location of the final waste disposal that can accommodate the waste in a long time. The determination of new TPA location must follow the standard criteria as written in SNI no. 03-3241-1994 and Peraturan Menteri Pekerjaan Umum Nomor 3/PRT/M/2013. In this study, the best TPA sites were determined through conformity analysis using spatial modeling. The parameters used in this modelling includes soil type, rock type, land use, land slope, traffic density, hydrogeology, rainfall, and administrative boundaries. The modelling result shows that there are 45 spots of potential location to be used as TPA of garbage with operating time more than 5 years.
\end{abstract}

Keywords: TPA Garbage, Spatial Modelling, SNI

Reka Geomatika - 23 


\section{PENDAHULUAN}

Penduduk Kabupaten Sumedang, tahun 2014, berjumlah 1.125.125 jiwa (BPS Sumedang, 2014). Perkiraan volume sampah yang dihasilkan adalah $3.270 \mathrm{~m}^{3}$, sedangkan volume sampah yang dapat ditangani oleh pemerintah kabupaten melalui Badan Lingkungan Hidup baru mencapai $150 \mathrm{~m}^{3}$ (Bappeda Sumedang, 2014). Angka tersebut dihasilkan dari 5 Tempat Penampungan Sementara (TPS) yang tersebar, yaitu TPS Gajah Agung, TPS Regol Wetan, TPS Kota Kulon, TPS Darangdan, dan TPS Kota Kaler/Pasar Sumedang Kota ditambah dengan tempat penampungan yang ada di Pasar Jatinangor, Cimanggung, Tanjungsari, Darmaraja, Wado, Ujungjaya, Conggeang, Cimalaka dan Buahdua serta dari lokasi-lokasi tertentu seperti perumahan. Seluruh sampah yang berhasil dikumpulkan selanjutnya ditempatkan di Tempat Pembuangan Akhir (TPA) Sampah di TPA Cibeureum Wetan, Kecamatan Cimalaka.

Dalam penanganan sampah ini banyak permasalahan yang dihadapi, mulai dari kurangnya gerobak dan truk pengangkut, terbatasnya lahan tempat pembuangan sampah, baik TPS maupun TPA, dan hal lainnya. Di lain pihak Pemerintah Kabupaten Sumedang sendiri sesungguhnya telah memiliki Peraturan Daerah Nomor 2 Tahun 2014 tentang Pengelolaan Sampah. Dalam Perda tersebut tercantum mengenai kebijakan dan strategi pengelolaan sampah yang memuat program pengurangan dan penanganan sampah. Dalam Perda tersebut dijelaskan bahwa TPA seharusnya dilengkapi dengan berbagai fasilitas dasar seperti jalan masuk, listrik, drainase, pagar, kantor dan fasilitas perlindungan lingkungan, fasilitas operasi, dan fasilitas penunjang. Namun, dalam penerapannya Perda ini belum sepenuhnya dapat terlaksana sehingga berakibat pada sedikitnya sampah yang dapat ditangani oleh pemerintah daerah.

Dari berbagai persoalan yang ada, lokasi TPA memegang peranan yang cukup penting. Hal ini dikarenakan kondisi TPA yang saat ini digunakan dianggap sudah tidak layak lagi. Dengan demikian perlu dilakukan penanganan permasalahan TPA ini segera melalui pencarian lahan yang dapat menampung sampah sesuai dengan volume sampah yang ada dan dapat bertahan dalam kurun waktu yang lama. Penetapan lokasi TPA Sampah harus mengikuti kriteria standar seperti yang tertulis dalam SNI No. 03-3241-1994 tentang Tata Cara Pemilihan Lokasi Tempat Pembuangan Akhir Sampah dan Peraturan Menteri Pekerjaan Umum Nomor 3/PRT/M/2013 tentang Penyelenggaraan Prasarana dan Sarana Persampahan dalam Penanganan Sampah Rumah Tangga dan Sampah Sejenis Sampah Rumah Tangga (BSN, 1994). Dalam standar ini disebutkan bahwa TPA harus memenuhi kriteria yang meliputi kriteria regional dan kriteria penyisih. Kriteria regional meliputi kondisi geologi, hidrologi, kemiringan, jarak dari lapangan terbang, dan bukan cagar alam atau daerah banjir. Adapun kriteria penyisih meliputi kriteria regional ditambah dengan kriteria iklim, kondisi tanah, demografi, batas administrasi, kebisingan, bau, estetika dan aspek ekonomi.

Dalam penelitian ini dilakukan penentuan lokasi TPA yang paling sesuai melalui analisis kesesuaian dengan menerapkan kriteria yang tertulis dalam SNI No. 03-3241-1994 dan Peraturan Menteri Pekerjaan Umum Nomor 3/PRT/M/2013. Analisis spasial dilakukan menggunakan pemodelan spasial dalam sistem informasi geografis. Adapun tujuan dari penelitian ini adalah menentukan dimana lokasi TPA sampah yang paling sesuai serta berapa lama jangka waktu penggunaannya. 


\section{METODOLOGI PENELITIAN}

Penentuan area TPA diperoleh dari pemodelan spasial yang dilakukan berdasarkan kriteria standar pada SNI No. 03-3241-1994 dan Peraturan Menteri Pekerjaan Umum Nomor 3/PRT/M/2013. Kedua aturan ini telah menetapkan besaran nilai dan bobot untuk parameter yang akan digunakan. Kriteria standar yang dimaksud meliputi kriteria regional dan kriteria penyisih. Kriteria regional meliputi:

a. kondisi geologi;

b. kondisi hidrogeologi;

c. kemiringan zona harus kurang dari $20 \%$;

d. jarak dari lapangan terbang harus lebih besar dai 3.000 meter untuk penerbangan turbo jet dan harus lebih besar dari 1.500 meter untuk jenis lain; dan

e. tidak boleh pada daerah lindung/cagar alam dan daerah banjir dengan periode ulang 25 tahun.

Adapun kriteria penyisih adalah kriteria regional ditambah dengan kriteria iklim, kondisi tanah, demografi, batas administrasi, kebisingan, bau, estetika, dan aspek ekonomi. Dalam SNI dan Peraturan Menteri PU secara jelas telah ditetapkan nilai dan bobot dari masingmasing parameter.

Dari keseluruhan parameter standar yang harus dipenuhi, maka ditetapkan beberapa parameter yang terkait dengan parameter fisik yang selanjutnya dipenuhi dari peta-peta yang diperoleh dari dinas-dinas terkait. Parameter-parameter, bobot, nilai serta sumber data yang digunakan dapat dilihat pada tabel 1 berikut ini.

Tabel 1. Data, Parameter, dan Sumber Data

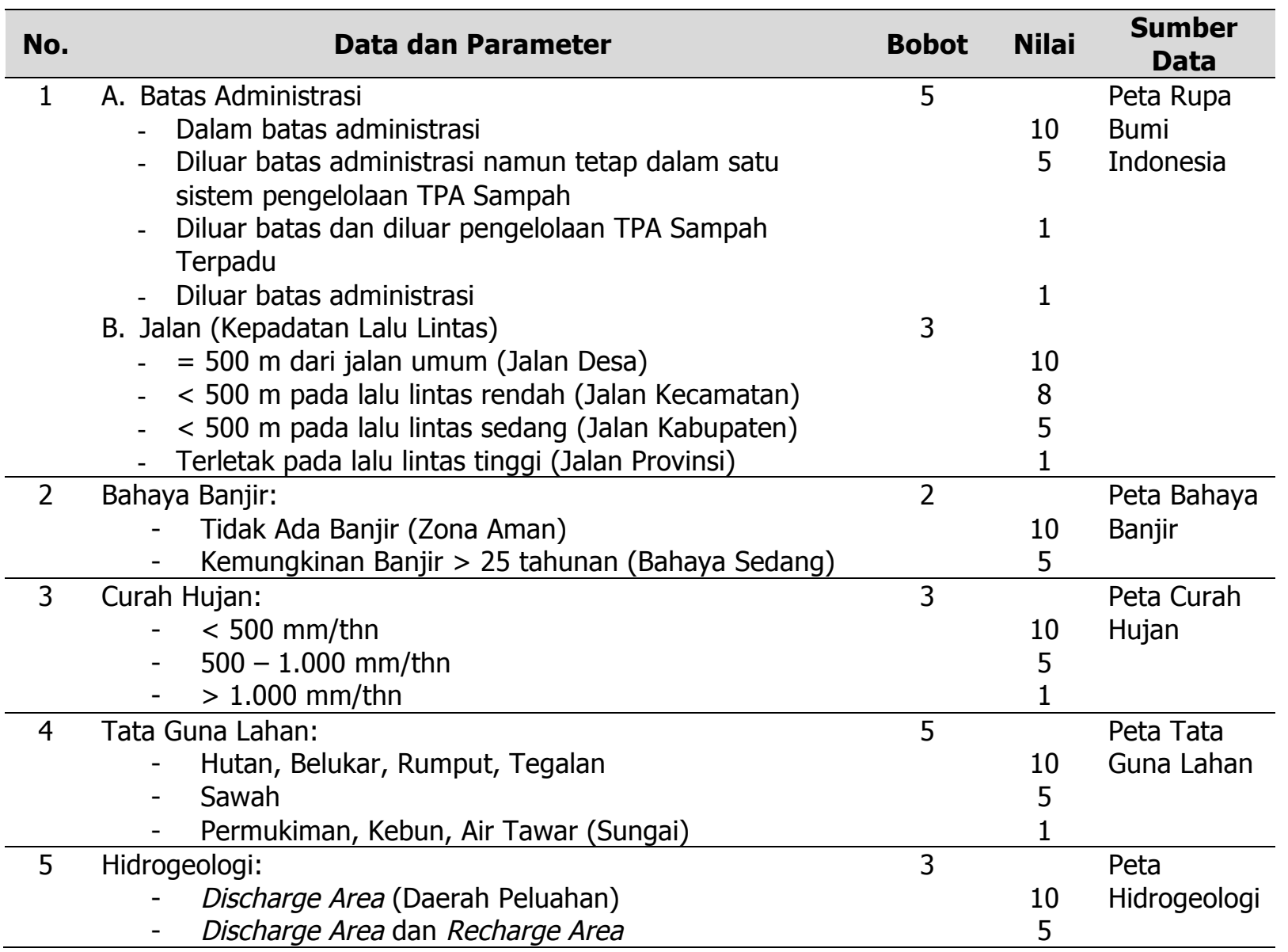




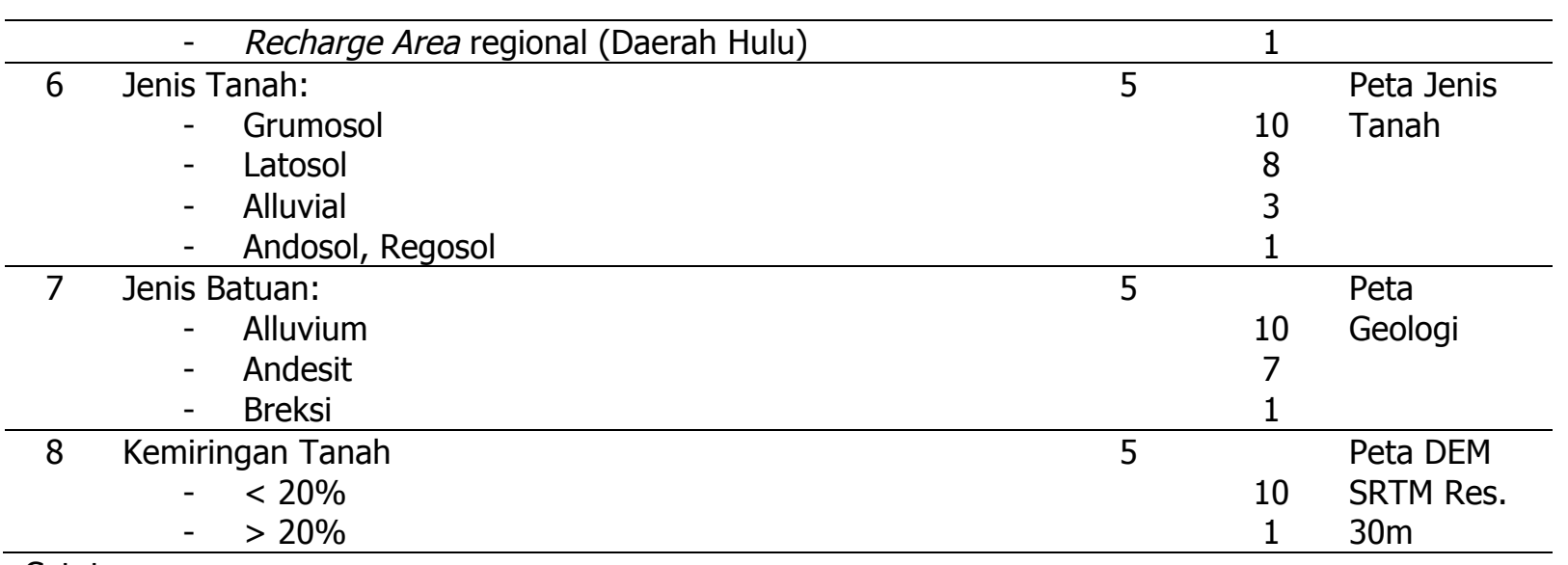

Catatan:

a. Peta Kepadatan Lalu Lintas merupakan gabungan dari data jalan yang diperoleh dari Peta Rupa Bumi yang diberi tambahan informasi kelas jalan yang merepresentasikan kepadatan lalu lintas dari Dinas Perhubungan

b. Data Kemiringan Tanah diperoleh dari analisis kemiringan yang diperoleh dari peta Digital Elevation Model (DEM) Shuttle Radar Topographic Mission (SRTM) yang bersumber dari United States Geological Survey (USGS) resolusi 30 meter.

Selanjutnya ditetapkan metodologi penelitian yang dapat dilihat pada gambar 1 . Peta yang digunakan dalam pemodelan spasial ini seluruhnya bersumber dari dinas-dinas di lingkungan Pemerintah Daerah Kabupaten Sumedang dengan skala peta yang bervariasi (Tabel 2).

Tabel 2. Jenis Peta dan Skala Peta yang Digunakan

\begin{tabular}{clll}
\hline No & \multicolumn{1}{c}{ Nama Data } & \multicolumn{1}{c}{ Skala } & \multicolumn{1}{c}{ Instansi Pemilik Data } \\
\hline 1 & Peta Tata Guna Lahan & $1: 25.000$ & Dinas Kehutanan dan Perkebunan \\
2 & Peta Jenis Tanah & $1: 100.000$ & Dinas Kehutanan dan Perkebunan \\
3 & Peta Hidrogeologi & $1: 250.000$ & Dinas Sumber Daya Energi dan Mineral \\
4 & Peta Geologi & $1: 250.000$ & Dinas Sumber Daya Energi dan Mineral \\
5 & Peta Rupa Bumi Indonesia & $1: 25.000$ & Badan Informasi Geospasial (BIG) \\
6 & Peta Curah Hujan & $1: 250.000$ & Dinas Sumber Daya Energi dan Mineral \\
7 & Peta Bahaya Banjir & $1: 300.000$ & Badan Perencanaan dan Pembangunan \\
& & & Daerah (Bappeda) \\
8 & DEM SRTM 1 Arc 30 m & - & USGS \\
\hline
\end{tabular}

Dalam analisis spasial yang dilakukan digunakan teknik overlay peta yang dinyatakan dalam diagram alir tahap 1 dan 2 yang dapat dilihat pada gambar 2 dan gambar 3 . Proses analisis dan overlay peta dilakukan menggunakan Sistem Informasi Geografis, dimana hasil pembobotan dan skoring diperoleh dengan menggunakan persamaan 1.

\section{Nilai Total $=($ W_GL $\times$ S $)+($ W_SL $\times$ S $)+($ W_HG $\times$ S $)+\left(W_{-}\right.$GL_1 $\times$S $)+($W_CH $x$ $S)+\left(W_{-} B J \times S\right)+\left(W_{-} J L \times S\right)+\left(W_{-}\right.$JT $\left.\times S\right)+\left(W_{-} B T S \times S\right)$}

Keterangan:

$$
\begin{array}{ll}
\text { W_GL } & =\text { Bobot Geologi } \\
\text { W_SL } & =\text { Bobot Slope (Lereng) } \\
\text { W_HG } & =\text { Bobot Hidrogeologi } \\
\text { W_GL_1 } & =\text { Bobot Tata Guna Lahan } \\
\text { W_CH } & =\text { Bobot Curah Hujan }
\end{array}
$$

$$
\begin{array}{ll}
\text { W_BJ } & =\text { Bobot Bahaya Banjir } \\
\text { W__L } & =\text { Bobot Jalan } \\
\text { W_JT } & =\text { Bobot Jenis Tanah } \\
\text { W_BTS } & =\text { Bobot Batas Administrasi } \\
\text { S } & =\text { Skor }
\end{array}
$$




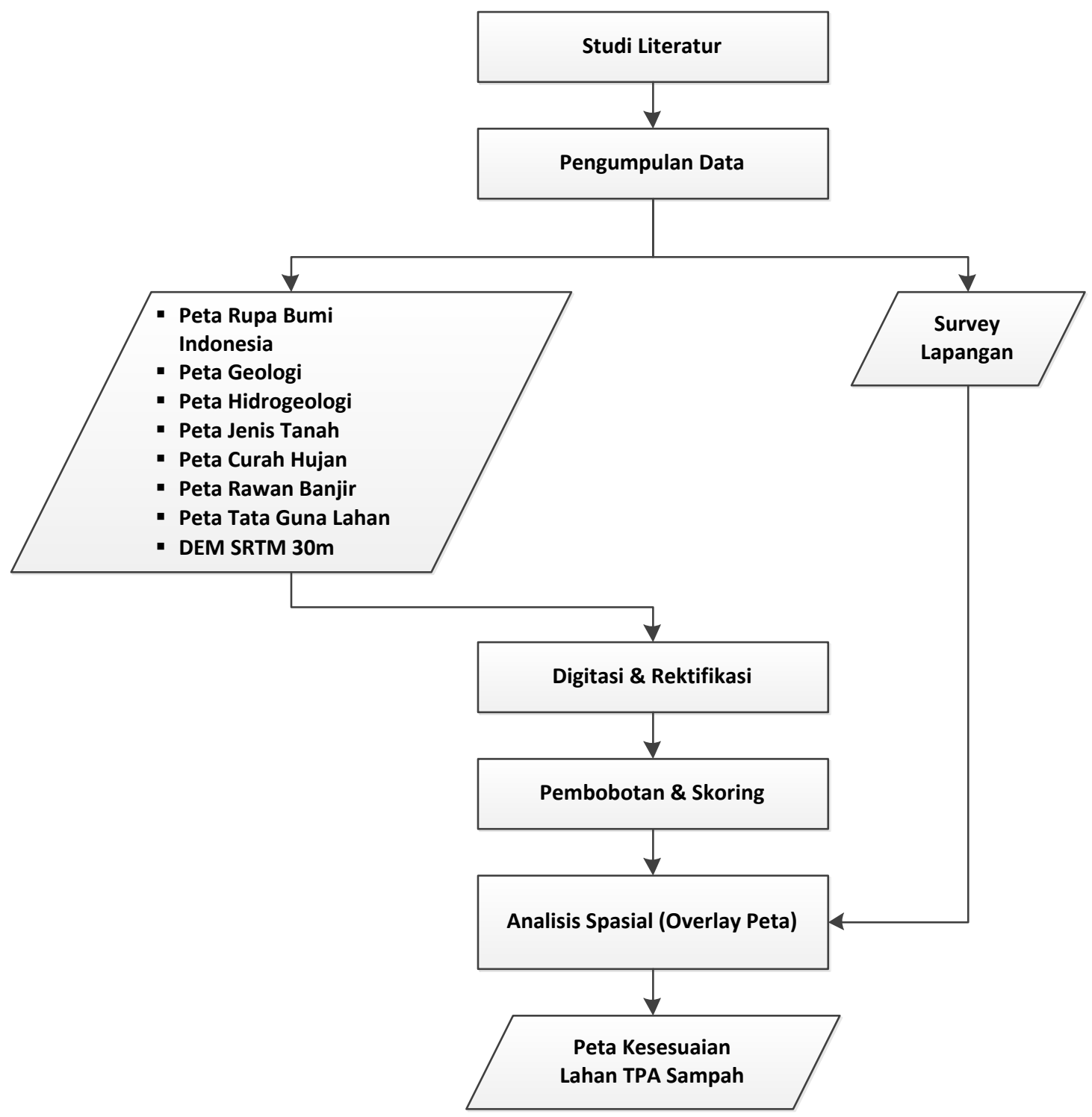

\section{Gambar 1. Metodologi Penelitian}

Untuk penentuan kelas tingkat kesesuaian dibuat dengan metode equal interval dengan persamaan 2 berikut.

$$
\text { Kelas Kesesuaian }=\frac{\text { Nilai Maks }- \text { Nilai Min }}{\text { Jumlah Kelas }}
$$

di mana:

- Nilai maks adalah nilai tertinggi dari hasil perkalian bobot dan skor

- Nilai min adalah nilai terendah dari hasil perkalian bobot dan skor

- Jumlah kelas adalah jumlah kelas kesesuaian 


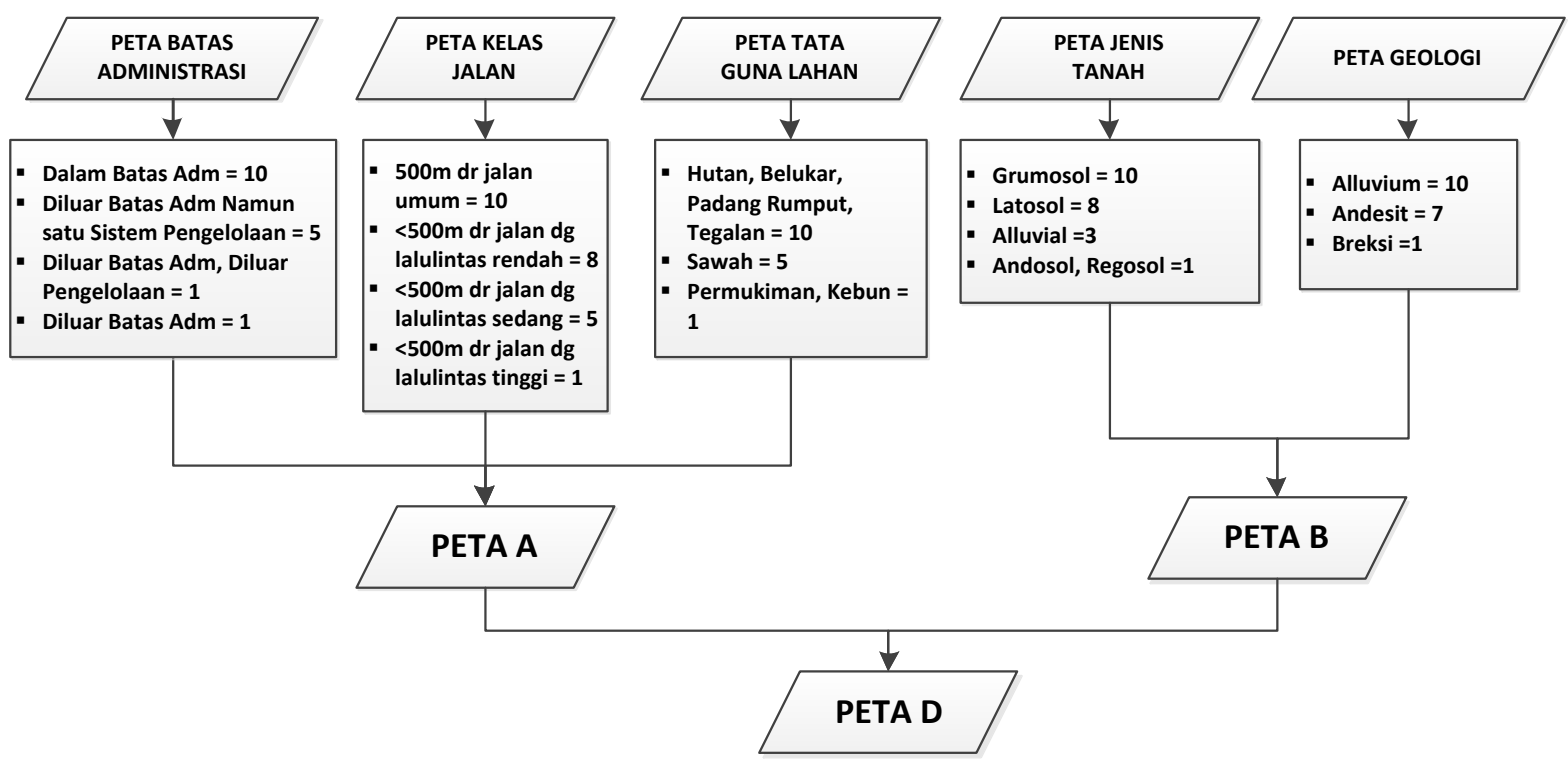

Gambar 2. Diagram Alir Kriteria dan Overlay Peta Tahap 1

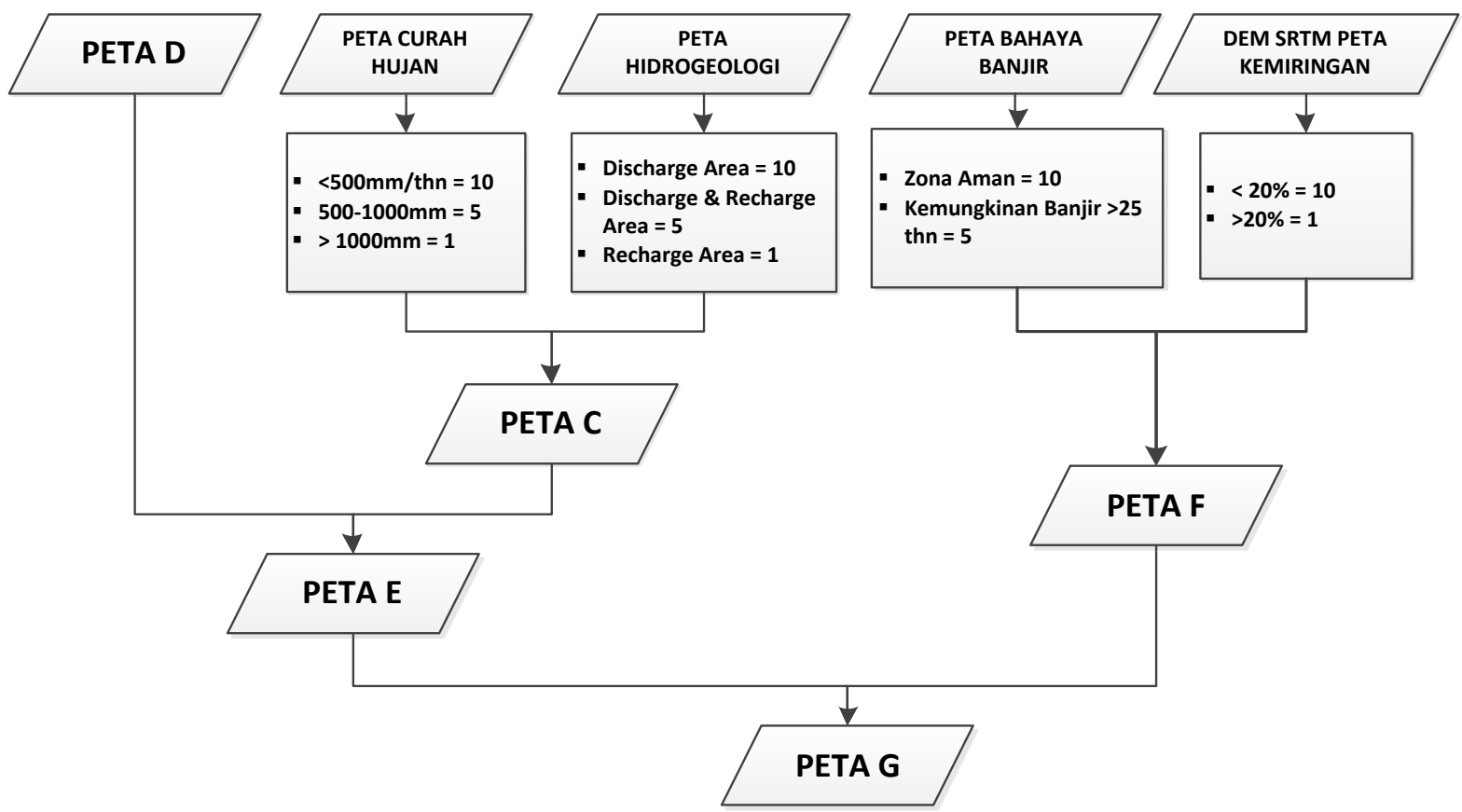

Gambar 3. Diagram Alir Kriteria dan Overlay Peta Tahap 2

Dalam penelitian ini jumlah kelas dibagi menjadi 4 kelas yaitu Sangat Sesuai, Sesuai, Cukup Sesuai, dan Tidak Sesuai. Adapun hasil dari perhitungan pembobotan diperoleh nilai dan luasan seperti yang tertera dalam tabel 2 di bawah ini. 
Tabel 2. Analisis Hasil Secara Kuantitatif

\begin{tabular}{crlr}
\hline No. & \multicolumn{1}{c}{ Range } & \multicolumn{1}{c}{ Analisis } & Luasan (Ha) \\
\hline 1 & $222.5-283.0$ & Sangat Sesuai & $13.061,025$ \\
2 & $162.0-222.5$ & Sesuai & $85.289,594$ \\
3 & $101.5-162.0$ & Cukup Sesuai & $59.742,570$ \\
4 & $41.0-101.5$ & Tidak Sesuai & $5.917,647$ \\
\hline \multicolumn{3}{r}{ Jumlah } & $\mathbf{1 6 4 . 0 1 0 , 8 3 6}$ \\
\hline
\end{tabular}

Untuk mengetahui kepemilikan lahan yang diperoleh, hasil analisis selanjutnya diajukan ke Badan Pertanahan Nasional (BPN) Kabupaten Sumedang guna mengetahui status kepemilikan tanahnya apakah merupakan tanah negara atau bukan.

\section{HASIL DAN ANALISIS}

\subsection{Hasil}

Pada gambar 1 diperlihatkan peta hasil analisis. Peta ini memperlihatkan lokasi-lokasi yang memenuhi kriteria standar SNI. Seluruh wilayah yang memenuhi kriteria sangat sesuai berjumlah 4.791 lokasi dengan luasan yang bervariasi. Namun dengan merujuk pada Peraturan Menteri Pekerjaan Umum Republik Indonesia No. 3/PRT/M/2013 yang menyebutkan bahwa TPA Sampah harus memiliki luas minimal $2 \mathrm{Ha}$, maka hasil analisis ini memberikan 433 lokasi yang sangat sesuai.

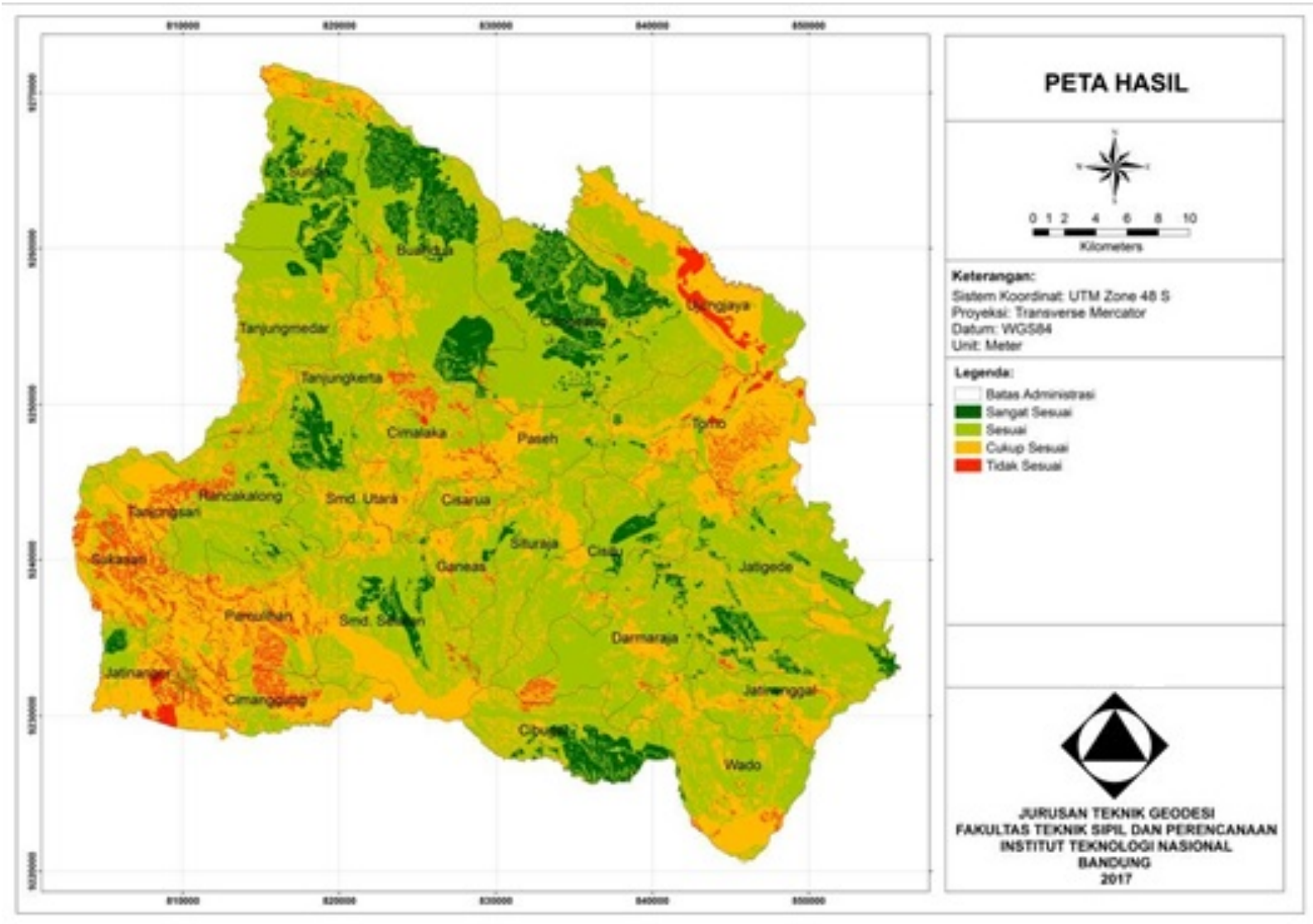

Gambar 4. Peta Hasil Analisis TPA Sampah 


\subsection{Analisis}

Berdasarkan analisis yang dilakukan diperoleh hasil bahwa lahan yang memenuhi kriteria standar yang telah ditetapkan dengan luas minimal 2 Ha adalah 433 lokasi. Namun perlu diketahui bahwa skala peta yang digunakan dalam proses analisis ini sangat bervariasi, sehingga ditetapkan bahwa luasan minimal yang dianggap sangat sesuai harus memiliki luas di atas $5 \mathrm{Ha}$. Hal ini berdasarkan perhitungan kesalahan terkecil pada proses digitasi peta skala terkecil yaitu skala 1:300.000. Dengan demikian dapat dinyatakan bahwa luasan $2 \mathrm{Ha}$ atau lebih kecil adalah luasan yang kemungkinan besar merupakan luasan yang diperoleh akibat kesalahan pada saat pendigitasian peta. Mengacu pada hal tersebut maka dapat diperoleh jumlah lokasi dengan luasan minimal 5 ha adalah 242 lokasi.

Terkait dengan lama waktu beroperasi TPA, SNI telah menetapkan bahwa lama waktu beroperasi untuk sebuah TPA minimal adalah 5 tahun. Hal ini diperoleh dari waktu tampung TPA yang merupakan hasil perkalian antara luasan dan kedalaman galian dibagi dengan suplai sampah di Kabupaten Sumedang yaitu $3.270 \mathrm{~m}^{3}$. Kedalaman galian sampah dibuat dalam 13 meter. Dengan asumsi lapisan sampah mencapai $1,5 \mathrm{~m}$ dan penutupan mencapai $30 \mathrm{~cm}$. Dengan demikian jika dibuat 7 lapisan maka akan diperoleh 12.6 meter. Hal ini dianggap cukup moderat, mengingat para perencana dapat menetapkan sampai dengan 10 lapisan dengan masing-masing ketebalan mencapai 2 meter (Astono dkk., 2015). Kedalaman ini selanjutnya dibulatkan menjadi 13 meter. Berdasarkan hal ini maka dapat diketahui bahwa terdapat 45 lokasi yang memiliki lama waktu operasi lebih dari 5 tahun, dengan luasan terendah terdapat di Desa Wanasari dengan luas 49,157 Ha dan lama waktu operasi 5,35 tahun. Adapun lokasi dengan luasan tertinggi terdapat di Desa Genderah dengan luas 976,731 Ha dan waktu operasi 106 tahun. Namun hal ini ditetapkan dengan catatan, produksi sampah di Kabupaten Sumedang berjalan dengan konstan, sehingga apabila produksi sampah semakin meningkat, maka waktu operasi pun akan semakin berkurang.

Berikut ini tabel 3 yang memperlihatkan sepuluh lokasi TPA terluas berikut lama waktu operasinya.

Tabel 3. Sepuluh Lokasi TPA Terluas

\begin{tabular}{cclllll}
\hline No. & $\begin{array}{c}\text { Luas } \\
(\mathbf{H a})\end{array}$ & \multicolumn{1}{c}{ Desa } & Kecamatan & $\mathbf{X}$ & $\mathbf{Y}$ & $\begin{array}{c}\text { Lama } \\
\text { Operasi } \\
\text { (Tahun) }\end{array}$ \\
\hline 1 & 976,731 & Desa Genderah & Buahdua & $823,759,198$ & $9,265,743,957$ & 106 \\
\hline 2 & 905,022 & Desa Genderah & Buahdua & $826,824,390$ & $9,262,513,921$ & 99 \\
\hline 3 & 701,561 & Desa Ungkal & Congeang & $837,337,246$ & $9,257,397,210$ & 76 \\
\hline 4 & 539,595 & Desa Cibitung & Buahdua & $828,012,671$ & $9,253,727,432$ & 59 \\
\hline 5 & 334,791 & Desa Sukaraja & Cibugel & $836,111,271$ & $9,228,077,743$ & 36 \\
\hline 6 & 313,310 & Desa Cipasang & Cibugel & $838,188,218$ & $9,227,220,913$ & 34 \\
\hline 7 & 283,356 & Desa Cibubuan & Congeang & $831,413,627$ & $9,258,518,838$ & 31 \\
\hline 8 & 282,848 & Desa Karanglayung & Congeang & $833,237,664$ & $9,256,593,244$ & 31 \\
\hline 9 & 267,347 & Desa Cacaban & Congeang & $834,691,651$ & $9,255,196,742$ & 29 \\
\hline 10 & 260,826 & Desa Ciranggem & Jatigede & $845,201,822$ & $9,235,922,947$ & 28 \\
\hline
\end{tabular}




\section{KESIMPULAN}

Berdasarkan hasil penelitian ini dapat disimpulkan bahwa terdapat 45 lokasi yang sangat sesuai untuk dijadikan TPA Sampah di wilayah Kabupaten Sumedang, dengan luasan 49-976 $\mathrm{Ha}$, dan lama waktu operasi antara 5 - 106 tahun. Waktu operasi ini akan menjadi semakin pendek apabila produksi sampah di Kabupaten Sumedang semakin meningkat. Sebaliknya pula, waktu operasi ini pun dapat menjadi semakin panjang apabila Pemerintah Kabupaten Sumedang belum dapat mengelola dan mentransport seluruh timbulan sampah setiap harinya. Seluruh lokasi potensial ini telah dikonfirmasikan ke Badan Pertanahan Nasional dan dinyatakan merupakan tanah milik Negara, sehingga hal ini akan memudahkan bagi Pemerintah Kabupaten Sumedang untuk pemanfaatannya.

\section{UCAPAN TERIMA KASIH}

Penulis mengucapkan terima kasih kepada para pimpinan dan staf Bappeda, BPS, Dinas Kehutanan dan Perkebunan, Dinas Sumber Daya Energi dan Mineral Kabupaten Sumedang serta Badan Informasi Geospasial atas bantuan data dan informasinya.

\section{DAFTAR PUSTAKA}

Astono, W., Purwaningrum, P., dan Wahyudyanti, R. (2015). Perencanaan Tempat Pembuangan Akhir Sampah dengan Menggunakan Metode Sanitary Landfill, Studi Kasus: Zona 4 TPA Jatiwaringin, Kabupaten Tangerang, Jurnal Teknik Lingkungan, 7(1), 7-16.

Badan Pusat Statistik Kabupaten Sumedang (BPS Sumedang) (2014). Kabupaten Sumedang Dalam Angka Tahun 2014: BPS Kabupaten Sumedang. Dipetik 15 Mei 2016, dari $<$ http://bappeda.sumedangkab.go.id/berita-204-permasalahan-sampah-di-kabupatensumedang.html>

Badan Standardisasi Nasional (BSN) (1994). SNI No. 03-3241-1994 tentang Tata Cara Pemilihan Lokasi Tempat Pembuangan Akhir Sampah. Jakarta.

Badan Perencaan Pembangunan Daerah Kabupaten Sumedang (Bappeda Sumedang) (2014). Tentang Permasalahan Sampah Di Kabupaten Sumedang. Dipetik 15 Mei 2016, dari <http://bappeda.sumedangkab.go.id/berita-204-permasalahan-sampah-di-kabupatensumedang.html>

Pemerintah Kabupaten Sumedang. (2014). Peraturan Daerah Nomor 2 Tahun 2014 tentang Pengelolaan Sampah. Dipetik 15 Mei 2016, dari

<http://jdih.sumedangkab.go.id/Prodhuk/perda/2014/ Peraturan.Daerah_2014_2.pdf>

Peraturan Menteri Pekerjaan Umum Nomor 3/PRT/M/2013. (2013). Dipetik 15 Mei 2016, dari <http://ciptakarya.pu.go.id/plp/upload/peraturan/Permen_PU_No_3_Tahun_2013_Penyelenggaraan_PS_Persampahan.pdf>

United States Geological Survey. (2016). DEM SRTM 1 Arc second - 30m. Dipetik 17 Mei 2016, dari <https://ta.cr.usgs.gov/SRTM1Arc> 